\title{
The Association Between the Voluntary Disclosure of Interim Reports and Company Characteristics in Jordan
}

\author{
Ala Albawwat Mohammad Shubita Zeyad Almatarneh Mazen Alomari \\ Faculty of Business, Accounting Department, Amman Arab University (AAU), Amman 11953, Jordan
}

\begin{abstract}
This research examines the potential association between the voluntary disclosure of reports published every six months and a company's characteristics. The focus is on selected variables that could influence the voluntary disclosure of information by ASE listed companies in Jordan. The estimation approach of the GMM dynamic panel system has used data selected from 120 ASE listed companies over a five-year period (2012 to 2016). This research also investigates the relationship between voluntary disclosure and the selected companies' attributes, such as audit committees and the audit firm's size as well as the company's size, profitability, leverage, industry type, number of employees, and whether it is foreign owned or shariah approved.The results of this study showed significant differences between the selected companies in the following areas: company size, industry type, company profitability, shariah approval, audit committees, audit company size and voluntary disclosure. The study found also that there is a significant relationship between voluntary disclosure and company size, profitability, type of industry, audit firm size, the audit committee and whether the company is shariah approved. Keywords: Jordan, voluntary disclosure, half-yearly financial reporting, interim financial reports.
\end{abstract}

JEL Classification: M420, G380, M410

DOI: $10.7176 / \mathrm{EJBM} / 11-32-02$

Publication date: November $30^{\text {th }} 2019$

\section{Introduction}

Organisations in the business industry have become well informed of the critical importance of giving out information on a broader form of activities including both the non-financial performance (socially responsible performance) and financial performance as stated by Akisik and Gal (2011). With the financial crises and corporate scandals that have loomed over the years, this calls for greater and more reliable corporate transparency within the world's businesses by some stakeholders, regulators, academic researchers, and investors. The notion of greater and reliable corporate transparency means information asymmetry is decreased between stakeholders and managers, characterised by better disclosure of information via different media sources, such as corporate web sites, annual reports, press releases and prospectuses (Uyar et al., 2013).

According to research compiled by Uyar et al. (2013), information disclosure could be categorised as either voluntary or mandatory. In voluntary disclosure, the management decides what information they choose to disclose. In mandatory disclosure, the law requires companies to present financial statements and the complementary footnotes.

It could, however, be observed that the degree with which information is disclosed is a crucial factor to consider in the short-term financial reports (Albawwat et al., 2015). Beyond this fact, the interim financial reports become the main source for potential investors and creditors in obtaining recent information on the companies' status. In this way, Saravanakumar et al. (2012) revealed in their work that most of the stock exchanges around the world today used to request companies to release their interim financial reports. For this reason, the primary stakeholders, such as investors, employees and other concerned shareholders, would be provided with high quality, reliable and timely financial information. This would subsequently serve as a suitable means to improve the financial decisions and investments of stakeholders.

Both corruption and re-evaluation have had a negative impact on the growth of the Jordanian economy. Over and above the country's economy, it is weighed down by huge government debts and economic issues linked to the 2008 financial crisis. According to the IMF 2014 report, the Jordanian public debt was estimated at JD 19 billion in 2013, which discouraged foreign investors and, in particular, those from developed countries. Jordan also felt the effects of the regional political conflicts and economic problems that took place between 2005 and 2013, which included the creation of the Islamic State of Iraq, al-Sham (ISIS) and the Arab Spring. Over this period Jordan's corporate performance suffered, which led to economic destabilisation (Albawwat et al., 2015).

The present research investigates the determining factors of voluntary disclosure in the context of an emerging market in Jordan. This study also calls on the regulatory bodies and relevant companies to improve their transparency in the competitive markets. The results of this research implicate firms, regulatory bodies and competitive markets. If potential regulators are to develop reliable corporate transparency, it is critical for them to have proper knowledge of the determinants for voluntary disclosure. In understanding the importance of information disclosure, managers could improve their determinants of disclosure practices. In the long run, it 
will improve stakeholder information. However, investors generate healthier and clearer decisions when studying their investments in the marketplace.

\section{Hypothesis Development and Theoretical Framework}

Concerning the degree of, or reports on, financial disclosure, many researchers referred to the study of Cerf (1961) as the basis of their empirical studies. The topic since then has created great awareness among academics from both developing and developed nations. The empirical studies that were recently conducted could be traced from developed nations, and later followed by the developing nations. Moreover, from the previous research carried out, the numbers of items listed under disclosure have been observed to be inferior compared to the studies.

The topic is of interest to academicians from both developing and developed nations. The empirical studies conducted recently were initially carried out in developed nations, and later in developing nations. Previous studies revealed that the numbers of items listed for disclosure were less than in recent studies. A US study focused on 34 items on a disclosure checklist, and their findings revealed that the habit of listed firms could affect the quality of disclosure (Singhvi and Desai, 1971). In a Swedish study, Cooke (1989) revealed the significant effect of voluntary disclosure on quotation status.

A considerable number of studies have also been conducted on disclosure in many other nations in the last decade like Cheung, Jiang \& Tan (2010) in China, Cheng \& Courtenay, 2006) in Singapore, Alsaeed, (2006) in Saudi Arabia, Hong Kong (Gul \& Leung, 2004), Turkey (Aksu \& Kosedag, 2006; Uyar et al 2013), Ghana (Bokpin \& Isshaq, 2009), in Qatar by Naser et al. (2006), in Malaysia by Haniffa \& Cooke (2002). It should be noted that earlier works were mostly evaluated based on the linkage between the scope of the voluntary disclosure and specific attributes of a given firm. However, the majority of these studies in the past were mainly focused on the financial report disclosure per annum, and only a few of them evaluated the interim financial reports

It is, therefore, a fact that in Jordan, there is limited data available on the study of interim financial reports. The present study would equally emphasise interim financial reports to enrich the current knowledge and provide a better understanding of interim financial reports' disclosure within a Jordanian context. Furthermore, standard awareness related to interim financial reports coupled with the proper adaptation of principles would be fostered. Any suggestion for amendment could be emphasised if there was the need for such and it would aim for the interim financial report's disclosure to successfully accomplish the aim of providing the rightful data to stakeholders in a timely and consistent manner, via proper evaluation. The findings from this research would positively impact other works on interim financial reports from a different perspective.

The theory of agency explains the relationship between the shareholders and managers of a firm and demonstrates why managers always plan to maximise their personal benefits (Jensen \& Meckling, 1976). The costs of the agency are incurred from the outcomes of information asymmetry and conflicts of interest between managers and owners. It is, however, expected for managers to provide more information so as to minimise the costs associated with agency theory (Giorgioni, Romilly \& Power, 2009, Hossain et al., 1995; Oyelere et al., 2003; Marston, 2003; Marston \& Polei, 2004; Hassan, Watson et al., 2002; Barako, Hancock \& Izan, 2006).

\subsection{Hypothesis Development}

\subsubsection{Company Size}

Company size is one of the attributes that could influence the degree of disclosure (Sejjaaka, 2007). Based on the agency theory, size could be seen as a reason for an increase in capital, which could be due to the expectations and the pressure from shareholders to protect their investments and from agent analysts looking for increased disclosure. Larger companies have a greater potential to provide information to suppliers, customers and the general public (Cooke, 1996). Agency costs are certainly higher in large companies, as shareholder distributions are greater. However, additional disclosure could eventually mitigate agency costs.

Company size was observed significantly variable in many relevant researches found with positive association between the extent of annual disclosure reports and company size (Wallace \& Naser, 1995; OwusuAnsah, 1998; Camfferman \& Cooke, 2002; Leventis \& Weetman, 2004; Barako et al., 2006; Lopes \& Rodrigues, 2007; Sejjaaka, 2007; Aljifri et al., 2014; Al-Janadi et al., 2013), and in interim financial reports as reveled by Schadewitz \& Blevins (1998); Mangena, and Tauringana (2007). Thus, the hypotheses were developed:

H1: There is a positive relationship between the level of voluntary disclosure in the half-yearly reports and size of a company.

2.1.2 Company Profitability

Cooke (1989) mentioned that company profitability was hypothesised to be positively associated with the degree of disclosure, based on certain proposed theories. Theory of agency suggests that managers from highly profitable firms could make use of external information in order to benefit personally. However, they must 
disclose the relevant information, so as to maintain their arranged compensation and position. Signaling theory states that it would be in the interest of company owners to provide the market with positive information, so as to avoid their company's shares being undervalued. The political process theory argues that highly profitable companies are more likely to regularly disclose information, so as to justify their profits (Inchausti, 1997).

However, at best, the empirical analysis results showed mixed evidence. Certain studies revealed that in the annual financial reports there was a positive relationship between the extent of disclosure and profitability (Camfferman \& Cooke, 2002; Haniffa \& Cooke, 2002; Hossain, 2008; Iatridis, 2008; Owusu-Ansah, 1998; Singhvi \& Desai, 1971; Wang et al., 2008). However, the Leventis and Weetman (2004) study showed a limited effect on profitability.

Other studies (Akhtaruddin, 2005; Alsaeed, 2006; Barako et al., 2006; Hossain \& Hammami, 2009; Sejjaaka, 2007) found no relationship between the extent of disclosure and profitability in the annual financial reports. The Ku Ismail and Chandler (2005) study revealed the same results in interim financial reports. In his research, Prencipe (2004) observed that profitability had little effect on the level of segment reporting. From this information, a hypothesis was developed.

H2: There is a positive relationship between the level of voluntary disclosure in the half-yearly reports and profitability of a company.

2.1.3 Industry Type

It has been observed that technical knowledge and accounting policies in companies vary according to industry specifications. Dye and Sridhar (1995) stated that companies in one industry could adopt disclosure practices that would not be applicable in other industries. Some industries are more regulated due to their overall importance in a country's national income. The nature of the disclosure could be linked to the scope of the business. Companies with multiple production lines could provide more information than companies with just one production line (Owsus-Ansah, 1998). Dominant firms with a higher level of disclosure in a particular industry may eventually lead other firms in the same industry (Belkaoui \& Kahl, 1978) to adopt a similar disclosure level (Wallace \& Naser, 1995).

Industry classification or type of industry based on which firms are collectively grouped is another determining factor that has been adapted considered so important in earlier studies by elaborating on the voluntary disclosure level. Most prior studies basically analyzed the possible linkage between industry type and voluntary disclosure. The Significant relationship between them was therefore observed as declared by many researchers (Meek et al. 1995; Haniffa and Cooke, 2002; Michelon and Parbonetti, 2010; Peters and Romi, 2011; Aljifri et al., 2014; Al-Janadi et al., 2013). In another round, some studies were unable to corroborate a significant association that could occur between industry type and disclosure level (Stanny and Ely, 2008; Cooper and Zainudin, 2009). The present study thus offers the following hypothesis:

H3: There is a direct relationship between industry type and the level of voluntary disclosure in the half-yearly reports.

2.1.4 Audit Firm Size

According to Xiao et al. (2004), agency theory maintained that auditing can potentially alleviate the conflict of interest between investors and management, as they have more to lose if their status is damaged. Larger audit firms possess a strong incentive to enforce stringent controls, remain independent and maintain extensive standard disclosure measures. It was observed that managers with more to gain from external monitoring have a greater tendency to hire large audit firms, which aligns with the signalling theory. Managers are sensitive to the larger auditors' incentives to require better quality disclosures, and the hiring of these auditors shows their acceptance of the requirement.

The audit firm size was linked to the degree of voluntary disclosure in earlier studies. It was hypothesized by many of them that the size of audit firm and level of disclosure were positively association. This was justifiable since Big-4 audit firms had better and higher experience as been global firms, they do not just accounts and audit reports based on annum, but equally had an impact on them as stated from the work of Wallace et al. (1994). Information that has been disclosed from auditing firms can be used by their potential clients to signaling their personal quality (Inchausti, 1997). Alsaeed, (2006) from his work further stated that audit firms are much giving more consideration to their reputation and, eventually run after high disclosure measure from clients. More so, the clienteles of Big-4 audit firms are henceforth expected to give out information of high quality level. It should be mentioned that some studies revealed a significant positive relationship between voluntary disclosure level and firm audit size as revealed be Singhvi \& Desai (1971); Patton \& Zelenka (1997); Inchausti (1997); Uyar, 2011 and Albawwat \& Ali basah (2015), whereas some postulated no significant relationship (Alsaeed, 2006; Chau \& Gray, 2010; Huafang \& Jianguo, 2007 and Wallace et al., 1994;). Thus, a hypothesis was brought up:

H4: There is a positive association between audit firm size and the level of voluntary disclosure in half-yearly reports. 


\subsubsection{Number of Employee}

There were no studies that investigated the relationship between the number of employees and the voluntary disclosure level in annual reports. Employees were left out of corporate governance (Blair \& Roe, 1999). This reflected in part the weak employee involvement in the US economic practices. In Germany or Japan, it is the opposite. Employee participation is politically crucial, taken into consideration and in most cases leads to competitive benefits (Brown, Nakata, Reich, \& Ulman, 1997). The of Khtaruddin et al. (2009) studies revealed a positive relationship between voluntary disclosure levels and the number of employees.

The resource-based theory could be adopted as well to evaluate the relationship between voluntary disclosure level and a number of the employee. The basic ideology behind resource-based theory is that the success of the company and competitive benefits relied on the resources available under control (e.g capabilities and assets) (Barney, 2001; Riahi- Belkaoui, 2003; Abeysekera, 2006). The assets of a company could be tangibles as well as intangibles as mentioned by Barney (2001). Since employees remain a good asset to the company, they have a huge role in play to the success of the company (Alhazaimeh et al., 2013). Therefore, involving voluntary disclosure components in the resource of a company contributes towards the creation of added value in a firm, which subsequently fosters general success in the company at large. It would be expected that for companies to give out more information about their resources (i.e. number of the employee) by including a voluntary disclosure with the ability to generate greater value to the company. Thus, the hypothesis has been developed:

H5: The level of voluntary disclosure in the half-yearly reports is positive association to the number of employees.

2.1.6 Shariah Approved Company

The Shariah is simply the basic teaching and guidance according to Islamic rules and regulations. Its teaching entails ultimate ethical codes for the Islam tradition (Sallehuddin \& Fadzil, 2013). In line with such notion, every action that was done by organizations or individuals in each Islamic businesses setting must strictly adhere to the teaching and guidance of Shariah. Further, Maali et al. (2006) in their work revealed that Shariah laws require Muslims being it organizations or individuals to accomplish their social mandate (Albawwat \& Ali basah, 2015). Generally, in some cultures, religion is considered to be a crucial factor in their community (Ousama \& Fatima, 2010). In Islam as a case sample, the religion guides how a Muslim lives their lifestyle and the way their business transactions are performed. Thus, this Islamic tradition significantly impacts on the domains of economics and accounting. With regard to accounting, the influence of Islamic tradition is much observed considering the level of disclosure (financial reporting) rather than measurement. This is because, the technical knowhow of basic accounting process is basically the same compared to the conventional system (Baydoun \& Willett, 1997).

Islamic teachings put the emphasis on appropriate disclosure rather than measurement techniques. When disclosing Islamic information, there are two general accounting prerequisites that need to be considered: the notion of complete disclosure and of social accountability (Haniffa \& Hudaib, 2002; Baydoun \& Willett, 1997; Haniffa, 2002).

Disclosing and reliable information have the tendency to help clients in the decision making the process from both religious and economic point of view. Relevant information is however needed by disclosing them, as the management would plan to achieve their obligations to the society and God (Haniffa \& Hudaib, 2002). Considering a detailed disclosure and social responsibility, financial report clients released by the Shariah Approved Companies (SAC) could expect pertinent information from voluntary disclosure, most especially, information to Islamic teaching. Additionally, shariah approved company is also found to positively with the level of voluntary disclosure (Albawwat \& Ali basah, 2015). Therefore, SAC capacitates in influencing the company's voluntary disclosure. Accordingly, the study proposes the hypotheses below:

H6: There is a positive association between shariah approved company and the level of voluntary disclosure in half-yearly reports.

2.1.7 Foreign Ownership

Haniffa and Cooke (2002) stated that there was a greater need for disclosure in order to monitor the management activities of foreign-owned companies. Ibrahim et al. (2004) also stated that foreign-owned companies need to open up and disclose all available and pertinent information to their investors and shareholders as fast as possible. So, this study expects to deduct an association between foreign ownership and timeliness. This is because foreign-shareholders could apply pressure to firms to issue financial reports in a timely manner so as to safeguard their interests in the business. Therefore, this study hypothesizes that:

H7: There is a relationship between foreign ownership and the level of voluntary disclosure in half-yearly reports.

2.1.8 Audit Committee

According to Ika and Ghazali (2012), the relationship between the timeliness of financial reports and the effectiveness of an audit committee is based on the opinion that an effective audit committee will meticulously 
manage the financial reporting, which will impact the results and the quality of the reports and produce a welltimed publication of financial information, as also revealed by Al Daoud et al. (2015).

More so, audit committee was observed as a sub-committee of the directorate board. The committee stands in playing an important role to assist the board with well-established corporate governance and also conduct additional responsibilities as required. An audit committee was described by Gay \& Simnett (2007) as a directorate committee that liaises with both external and internal audit and external financial reporting from oversees. As the committee carried out the major tasks, its main objective is to oversee the process of financial reporting (Klein, 2002a). The audit committee was equally seen as an important institution with regard to corporate governance as they help the board to achieve their financial duties and other duties towards shareholders. Abdullatif (2010) then postulated that the directors must develop and sustain a direct-line of communication within themselves and internal and external auditors through the activity of audit committees. However, Buchalter and Yokomoto (2003) gave their own contribution as major objective of an audit committee remains to ensure the accuracy and timely manner of financial reports.

Considering those aims been highlighted from earlier studies, the present study also investigates the possible relationship between the audit committee and the timeliness of financial reports. An audit committee is observed generally as an important factor to consider in the structure of overall corporate governance in a firm. To be specific, mistake or inaccuracy the quality auditing and financial reporting oversight. Therefore, in proper monitoring responsibilities, the audit committee is expected to provide feedback process to the management so as to achieve information in a timely manner. Thus, based on the previous findings, the fifth hypothesis of this study is as follows:

H8: The presence of an audit committee is associated positively with the level of voluntary disclosure in halfyearly reports.

2.1.9 Control Variable

To test the main hypotheses, this paper includes a number of control variables (company leverage, listing status and liquidity). The included variables are drawn from reports related to voluntary disclosure.

\section{Methodology of Research \\ 3.1 Data}

This study focused on the interim reports as mandated by the Directives for Listing companies on the ASE and developed by the ASE listed Jordanian companies over a period of 5 years - between 2012 and 2016. One hundred and twenty non-financial firms were selected From the ASE list. The financial companies were excluded, as the laws guiding financial reporting in this sector are different. The regulatory bodies responsible for financial companies are guided by the Jordanian Central Bank and the Insurance Commission.

It should put into consideration that both the availability of data together with completeness are other determining factors capable to influence selection criteria of a given firm within with the time frame of this study. 
3.2 Definitions of Variables

Table 1: the variables defination.

\begin{tabular}{|c|c|c|}
\hline VARIABLE & ACRONYM & MEASUREMENT \\
\hline \multicolumn{3}{|l|}{ Dependent Variables } \\
\hline Voluntary disclosure & VD & $\begin{array}{l}\text { The disclosure index checklist is used to measure the degree of } \\
\text { voluntary disclosure Albawwat \& Ali basah ( 2015), Al-Shammari } \\
\text { and Al-Sultan (2010) Jiang and Habib (2009), Elsayed and Hoque } \\
\text { (2010), Akhtaruddin and Haron (2010), Lopes and Alencar (2010), } \\
\text { and Mangena and Tauringana (2007).. }\end{array}$ \\
\hline \multicolumn{3}{|l|}{ Independent Variables } \\
\hline Company size & CSIZE & $\begin{array}{l}\text { The size of the company will be measured by the total assets (a } \\
\text { natural logarithm of total assets), following (e.g.Ku Ismail \& } \\
\text { Chandler, 2005; Alsaeed, 2006; Omar and Simon, 2011; Al-Janadi et } \\
\text { al. 2013). }\end{array}$ \\
\hline Profitability & PROF & $\begin{array}{l}\text { The profitability will be measured by the return on assets (operating } \\
\text { income divided by total assets), following (e.g.Prencipe, 2004; Omar } \\
\text { and Simon, 2011; Ntim et al. 2013). }\end{array}$ \\
\hline Industry type & INTYPE & $\begin{array}{l}\text { The industry type there are two types of categories to be measured: } \\
\text { (IN1) one for manufacturing companies and zero otherwise, also } \\
\text { (IN2) one for services companies and zero otherwise, following } \\
\text { (e.g.Barako et al. 2006; Omar and Simon, 2011). }\end{array}$ \\
\hline Audit Firm Size & AFSIZE & $\begin{array}{l}\text { Measured by (1) if a firm has audited from big four audit firms and } \\
\text { (0) if otherwise (Alhazimeh at al., 2014, Naser et al., 2002). }\end{array}$ \\
\hline Number of employees & NLAB & $\begin{array}{l}\text { This variable is measured by the total number of employees for each } \\
\text { company. This measurement of the percentage of non-executive } \\
\text { directors was used by some prior studies (e.g. Khtaruddin et al., } \\
\text { 2009; Alhazimeh at al., 2014). }\end{array}$ \\
\hline $\begin{array}{l}\text { Shariah } \quad \text { Approved } \\
\text { Company }\end{array}$ & SHAC & $\begin{array}{l}\text { The value of ' } 0 \text { ' to the firm that is non-Shariah approved while; the } \\
\text { value of ' } 1 \text { ' will be assigned to the firm that is Shariah approved Al- } \\
\text { Shammari (2013). }\end{array}$ \\
\hline Foreign ownership & FOW & $\begin{array}{l}\text { The foreign ownership, measured by the log of the percentage of } \\
\text { shares owned by foreigners to a total number of shares issued Al- } \\
\text { Janadi et al. (2013) and Aljifri et al. (2014). }\end{array}$ \\
\hline Audit committee & ACOM & $\begin{array}{l}\text { Code (1) if audit committee exists while code (0) if audit committee } \\
\text { does not exist Mangena and Tauringana (2007), and Allegrini and } \\
\text { Greco (2011). }\end{array}$ \\
\hline \multicolumn{3}{|l|}{ Control variables } \\
\hline Listing Status & LS & Code (1) is assigned for listed while 0 for unlisted. \\
\hline Liquidity & LQT & Current assets divided by current liabilities \\
\hline leverage of compan & LGLEVE & Log of the debt / total assets ratio \\
\hline
\end{tabular}

$$
\begin{aligned}
& 3.3 \text { Model Development } \\
& \begin{aligned}
V D_{i t}=C+\beta_{1} V D_{i t-1}+\beta_{2} C_{\text {it }} I Z E_{i t}+\beta_{3} P R O F_{i t}+\beta_{4} I N T Y P E_{i t}+\beta_{5} A F S I Z E_{i t}+\beta_{6} N L A B_{i t}+\beta_{7} S H A C_{i t} \\
+\beta_{8} F O W_{i t}+\beta_{9} A C O M_{i t}+\beta_{10} L S_{i t}+\beta_{11} L Q T_{i t}+\beta_{12} \text { LGLEVE }_{i t}+\sum_{\mathrm{t}=2011} Y E A R_{\mathrm{t}}+u_{i}+\varepsilon_{i t}
\end{aligned}
\end{aligned}
$$

\subsection{Dynamic Panel GMM}

The Generalized Method of Moments (GMM) has been known as a dynamic panel approach and it was adopted in this research. Developed by Arellano and Bover (1995) and Blundell and Bond (1998), the GMM system is known to improve the efficacy of first difference GMM. Further to this, GMM also addresses the possible effects of voluntary disclosures in the past in relation to the current one. In terms of sampling, these approaches make use of the one with shorter time but with a huge number of firms though. Two (2) equations levels are related to GMM, and from the first difference, Instrumental Variables (IV) is adopted by each equation to remove the correlation between the variables that are explanatory and residuals (Albawwat \& Ali basah, 2015).

In the process of handling the short-sample periods, heteroskedasticity, heterogeneity together with explanatory, autocorrelation variables that are predetermined and endogenous, positive benefits could be impacted in adopting GMM approach. This is true as the efficiency of estimation would dramatically improve under this approach. For this fact, it is necessary to use suitable instruments so as to ensure a successful and 
reliable outcomes by the GMM as this would avoid any unbiased results. In answer to that the over identifying restrictions test of Hansen/Sargan, AR (2), and the difference in Hansen are the three appropriate test of diagnosis.

The model of Hansen/Sargan to test for over-identifying restrictions scrutinizes in detail the validity of the overall instruments. This achievable in properly examining the time frame of analogue sample condition adopted in the process of estimation. Here, instrument involved were assumed valid. The model was also specified as the conditional moment was held. Meanwhile, the AR (2) performance test has been based on residuals, as it was basically to ascertain to be sure of no serial correlation could take place among the transformed error terms. The variance in the model of Hansen test was adopted to evaluate the validity of conditional extra-moment from the GMM system. From variance the test, among Hansen statistics obtained from GMM model and the difference in GMM were determined. At the end, If the estimated model was supported all the three null hypotheses would be considered rejected as mentioned by Albawwat \& Ali basah (2015).

\section{Results}

\subsection{Descriptive Statistics}

The descriptive statistics on the general voluntary disclosure level for non-financial as well as financial information, voluntary strategic information for the period between 2012 and 2016 can be viewed in Table 1 .

Table 1: Descriptive Statistics

\begin{tabular}{|l|c|c|c|c|c|c|}
\hline Year & 2012 & 2013 & 2014 & 2015 & 2016 & (VD Overall) \\
\hline Mean \% & 49.6 & 56.4 & 60.5 & 67.2 & 71.5 & 61.04 \\
\hline Median\% & 34.7 & 39.5 & 42.3 & 47.1 & 50.1 & 42.30 \\
\hline St. Deviation \% & 34.2 & 38.9 & 41.7 & 46.4 & 49.3 & 5.35 \\
\hline
\end{tabular}

Sources: Amman Stock Exchange Report $(\mathrm{N}=120)$

As shown in Table 1, the means value obtained on overall voluntary disclosure from interim reports in a half year as available under the listed Jordanian's companies between the years 2012-2016, was 61.04\%. In a simpler way, on average, the listed Jordanian's companies revealed $61.04 \%$ of the 67 key items of voluntary disclosure within the said time frame work.

When compared to the recent researches conducted in Jordan, earlier studies conducted by Cong and Freedman (2011) in United States (35.26\%), Ho and Wong (2001) in Hong Kong (21.75\%,), Arcay and Vazquez (2005) in Spain (42.38\%), Jiang et al. (2011) in New Zealand (27.38\%,), and Binh (2012) in Vietnam (43.36\%) demonstrated a lower level of overall voluntary disclosure on average.

From the works of Akhtaruddin and Haron (2010), Botosan (1997), Kurawa \& Kabara (2014), and Cormier et al. (2012), with the following average percentage of disclosure: $64 \%, 65 \%$ and $74.33 \%$ accordingly, revealed an overall level of voluntary disclosure that was higher compared to the present research.

The information acquired from various studies on voluntary disclosure showed mixed results when compared to this particular study. This could be due to the following factors: The current research measured voluntary disclosure differently. More items (67) were included, making it more comprehensive than earlier studies. Studies, such as that of Kurawa and Kabara (2014), provided a high level of voluntary disclosure; however, there were only between 22 and 34 key items. When expressed as a ratio, the smaller denominator would show a higher degree of voluntary disclosure.

Besides this, various sample sizes were used in various studies and this led to the variance in the results. For instance, studies that outputted high degree of voluntary disclosure were characterized by the small size of samples ranging from 38 to 50 listed firms as revealed by and Kurawa and Kabara 2014 and Akhtaruddin and Haron (2010). More so, the diversity within the sample's period is another factor capable to influence the results. In fact, the practice of voluntary disclosure among companies has the tendency to vary with the time factor. Therefore, as the different researches were carried out in different given times, it is more likely for the outcomes gained to be varied as well.

Studies conducted in companies in different countries showed that the results could vary according to the voluntary disclosure practices they adopted. As an example, voluntary disclosure practices in more advanced nations are less conventional than in developing nations. Thus, a high level of voluntary disclosure is expected in the financial reports of firms in more advanced nations.

The different information types for periodic voluntary disclosure between 2012 and 2016 were as follows: strategic information 59\%, non-financial information 56\% and financial information 52\%. On average, Jordanian firms disclosed information on 16 out of 26 voluntary strategic items, on 13 out of 21 voluntary non-financial items and on 11 out of 20 voluntary financial items between 2012 and 2016 . Based on these results, the listed Jordanian firms were able to voluntarily give out more strategic information than financial or non-financial information. 


\subsection{Generalized Method of Moments (GMM)}

Table 2 demonstrates the model of GMM test on the characteristics of corporate governance that involved company size, the profitability of company, audit firm size, leverage of company, industry type, number of employees, shariah approved company, foreign ownership and audit committee.

The AR(2) model was used to test for sequential correlation and the Hansen model test was used to evaluate valid instruments, and the outputs indicated that all the data was valid. In Table 2, both the AR(2) and the Hansen model tests in their p-values were found to be greater than 0.10 . The statistical analysis showed a nonsignificant difference at a 10\% significance level. The empirical model accurately specified that there was no serial correlation (autocorrelation) in the residuals transformation and the instrumental validation is in line with the periodic conditions adopted in the specified models. The added periodic conditions were statistically insignificant as was the difference in the Hansen test that was not reported on.

Table 2: Dynamic panel-data estimation, one-step system GMM

\begin{tabular}{|l|c|l|}
\hline Variables & Coefficients & P-Value \\
\hline Voluntary index & 0.224 & $0.000^{* * *}$ \\
\hline Company size & 0.105 & $0.006^{* * *}$ \\
\hline Profitability of company & 0.084 & $0.030^{* *}$ \\
\hline Industry type & 0.000 & $0.032^{* *}$ \\
\hline Audit firm size & 3.221 & $0.019^{* *}$ \\
\hline Number of employees & 0.218 & 0.214 \\
\hline Shariah approved company & 4.958 & $0.012 * *$ \\
\hline Foreign ownership & 1.265 & 0.334 \\
\hline Audit committee & 0.058 & $0.041^{* *}$ \\
\hline Listing Status & 0.000 & $0.032^{* *}$ \\
\hline Liquidity & 0.006 & 0.285 \\
\hline Leverage of company & 0.047 & $0.024 * *$ \\
\hline Number of instruments & 99 & \\
Number of observations & 495 & \\
Number of groups & 120 & \\
AR(2)-p value & 0.781 & \\
Hansen/Sargan test -p value & 0.977 & \\
\hline Note (1): . & & \\
\hline
\end{tabular}

Note (1): $* * *, * * *$ denote $10 \%, 5 \%$ and $1 \%$ significant levels, respectively.

The estimated outcomes from the one-step GMM model, as demonstrated in Table 2, revealed that over time there was a growing trend for voluntary disclosure. The recent voluntary disclosure research was mainly based on previous disclosure studies. Based on the study of the half-year results, it would appear that there is a significant relationship between voluntary disclosure and company size, profitability, type of industry, audit firm size, the audit committee and whether the company is shariah approved.

To test whether company size could have an impact on the extent of voluntary disclosure level. Variable of company size was significantly positive under $1 \%$ level and this indicated that company size could definitely have the effect on voluntary disclosure level positively. This claim back up the first Hypothesis (H1) regarding company size. Hence, a positive relationship was observable between the level of voluntary disclosure in the half-yearly reports and company size. This finding is in line with many earlier studies like that of Hossain \& Hammami (2009); Eng \& Mak (2003); Alsaeed (2006); Huafang \& Jianguo (2007); Chau \& Gray (2010); Uyar et al. (2013) and Hossain \& Reaz, 2007). More so, the impact from company size on the degree of disclosure could be justified for simple because, bigger companies possess better structure of organization, well-developed model of information, better complex operational activities and diversified in a more better way. All the mentioned factors might probably be able to be responsible for bigger firms keep on top of smaller firms based on voluntary disclosure.

As observed from the results in Table 2, profitability (ROA) was significant and positive at 5\% level. It was therefore suggested that profitability could positively affect the level of voluntary disclosure. The findings connote to the second Hypothesis regarding profitability. Hence, there was a positive relationship between the profitability of the company and the degree of voluntary disclosure in the half-yearly reports. Similar results were confirmed from earlier studies carried out by, Gul and Leung (2004), Cheng and Courtenay (2006) and Haniffa and Cooke, (2002) who equally discovered positive significant relationship.

More so, the result of the industry type was statistically significant and positive at $5 \%$ level and it suggested that industry type also had positive effect on the voluntary disclosure level. Then Hypothesis 3 was supported based on the obtained findings in line with Industry type. Hence, there was a positive relationship between the level of voluntary disclosure in the half-yearly reports and the type industry involved. This finding is confirmed with (Meek et al. 1995; Haniffa and Cooke, 2002; Omar and Simon, 2011; Al-Janadi et al., 2013; Aljifri et al., 
2014) who found no significant association.

The estimated outcomes from the one-step GMM model, as demonstrated in Table 2, revealed that over time there was a growing trend for voluntary disclosure. The recent voluntary disclosure research was mainly based on previous disclosure studies. Based on the study of the half-year results, it would appear that there is a significant relationship between voluntary disclosure and company size, profitability, type of industry, audit firm size, the audit committee and whether the company is shariah approved.

Table 2 further indicated a significant difference between the audit firm size and voluntary disclosure at a 5\% level. The Big Four auditing firm clients were found to be more likely to provide voluntary information. In the half-year reports, Hypothesis 4 confirmed the positive link between audit firm size and the level of voluntary disclosure. The results from this study concur with the findings of a number of researchers (Inchausti, 1997; Patton \& Zelenka, 1997; Omar \& Simon, 2011; Uyar et al., 2013), who found a similar significant positive association.

The findings based on the number of employees was not statistically significant. The results negated some earlier studies carried out by Brown et al. (1997), Blair and Roe (1999) and Alhazimeh et al. (2014), as they found that the participation of labour was politically relevant and often provided a competitive advantage. Earlier, the empirical outputs GMM model, as seen in Table 2, revealed that in the Jordanian listed firms' half-year reports, employee numbers were not a determining factor in the degree of voluntary disclosure. This could be due to the fact that employees were not being taken into account by corporate governance or by previous studies. Therefore, the Hypothesis 5 (H5) claim does not support it.

In contrast, shariah approved companies ware significantly positive $5 \%$ level which signified that the voluntary disclosure level was positively affected by shariah approved companies. The findings in relation to the Hypothesis 6 was confirmed the be matched regarding shariah approved companies. Hence, it could be deducted that in half-yearly reports, a positive association could exist between shariah approved companies and the level of voluntary disclosure. This result finding is in agreement with the study of Haniffa and Hudaib (2002) who equally suggested that full disclosure of pertinent and reliable information would definitely assist the outside clienteles' economic and religious decisions making process. The authors further, indicated that making this disclosure, the management would fulfill their duties to God and the society. Again, the clienteles of the financial reports published by the shariah approved companies would be expecting relevant information based on the voluntary disclosure process that is in line with the Islamic teaching and this is, of course, part the companies' fulfillment of social responsibility where ever they are established (Albawwat \& Ali basah, 2015).

Another result from Table 2, found no significant association between foreign ownership and voluntary disclosure in the half-year reports. The insignificance of foreign ownership on voluntary disclosure among the ASE Jordanian listed companies could be explained by certain factors. Firstly, being an employee in a foreigninvestment firm in Jordan does not affect the employees' ethical attitudes. Secondly, multinational companies in developing countries differ from their company's headquarters in developed countries, as the ethical standards being imposed in the developing countries may not be as complex as those imposed in developed countries. Hence, Hypothesis 7 and the link to foreign ownership is negative. This claim is supported by studies carried out by a number of researchers (Eng \& Mak, 2003; Cheng \& Courtenay, 2006; Luo, Courtenay, \& Hossain, 2006; Abdelsalam \& Weetman, 2007; Hajji \& Ghazali 2012).

The results from the audit committee show that there was statistical significance (positive) at a level of $5 \%$, which means that the auditing committee could yield positive effects on the degree of voluntary disclosure. These findings supported Hypothesis 8, as a positive relationship was observed between the level of voluntary disclosure in the half-year reports and the audit committee. Similar findings were revealed in studies conducted by a number of researchers (Vazquez, 2005; Li et al., 2008; Persons, 2009; Arcay et al., 2012; Barako et al., 2006; Wong, 2001), who found positive significance associated with the degree of voluntary disclosure.

In summary, empirical outputs from the GMM model of analysis supported the hypotheses that the degree of voluntary disclosure found in half-year reports could be influenced by company size (H1), company profitability (H2), industry type (H3), audit firm size (H4), shariah approval (H6) and audit committees (H8). In contrast, the results did not support the hypothesised theory of the influence of employee numbers or foreign ownership on the degree of voluntary disclosure in the Jordanian listed companies' half-year reports.

\section{Conclusion}

The main objective of this research was to discover what factors would have an impact on the level of voluntary information disclosure by Jordanian listed firms over a period of four years (2012-2016). Previous studies mainly researched the determinants of voluntary information disclosure. Firstly, unlike some earlier studies conducted in developed nations, this research examined the voluntary information disclosure models of selected firms in Jordan, which had more relevance in less developed countries. Secondly, the aim of the present study was to test eight hypotheses and a comprehensive set of variables in order to provide evidence of companies' disclosure practices in their half-year reports. Empirical facts in relation to the possible effects of these variables 
on the degree of information disclosure were provided in the half-year reports.

It has also been demonstrated in this study that the level of disclosing information in Jordan was considered moderate. Although the body that regulates the Capital Markets making reference to the principles of corporate governance could add more values to activities of voluntary disclosure of firms. It is thus a necessity to keep improving this practice to high standard levels. More still need to be done for better achievement, most especially in the practice of forward-looking information, social responsibility, human resources, risk management-related disclosure, and environmental disclosure.

This study provided evidence of a positive relationship that could occur between the degree of voluntary information disclosure and the variables chosen (company size, the profitability of company, industry type, audit firm size, shariah approved company and audit committee). The remaining variables, namely, a number of employees and foreign ownership were found to have an insignificant effect.

Furthermore, the research identified some of the implications for the selected firms, auditors, potentials investors and regulators. Together, they play a crucial role in adding value to the level of transparency and corporate disclosure practices. Firms have the tendency to increase voluntary information disclosure, based on the advantages gained from doing so, and investors are liable to demand higher disclosure from the company's management. Finally, auditing firms may also add more value to the firm's corporate culture by developing their disclosure practices.

\section{References}

Abeysekera, I. (2006). The project of intellectual capital disclosure: researching the research. Journal of Intellectual Capital, 7(1), 61-77.

Akhtaruddin, M., \& Haron, H. (2010). Board ownership, audit committees' effectiveness, and corporate voluntary disclosures. Asian Review of Accounting,18(3), 245-259.

Akhtaruddin, M., Hossain, M. A., Hossain, M. \& Yao Lee. (2009) Corporate Governance and Voluntary Disclosure in Corporate Annual Reports of Malaysian Listed Firms. The Journal of Applied Management Accounting Research. Vol.7 No.1.

Akisik, O.; Gal, G. (2011). Sustainability in businesses, corporate social responsibility, and accounting standards: An empirical study. International Journal of Accounting and Information Management, 19(3): 304-324. http://dx.doi.org/10.1108/18347641111169287

Aksu, M.; Kosedag, A. (2006). Transparency and disclosure scores and their determinants in the Istanbul Stock Exchange. Corporate Governance, 14(4): 277-296. http://dx.doi.org/10.1111/j.1467-8683.2006.00507.x

Al-Ajmi, J. (2008) Audit and reporting delays: Evidence from an emerging market. Advances in Accounting. Vol.24(2). 217-226.

Albawwat, A. and Ali Basah, M. (2015) The Impact of Shariah Approved Companies on the Relationship between Corporate Governance Structure and Voluntary Disclosure of Interim Financial Reporting in Jordan. International Journal of Academic Research in Accounting, Finance and Management Sciences. Volume 5, Issue 2.

Albawwat, A., Ali Basah, M., and Faizal Khairi, K. (2015) The Relationship between Voluntary Disclosure and Company Performances on Interim Reports in Jordan Using the Method of Causality Directions. International Journal of Economics and Finance. Vol. 7, No. 7.

Al-Janadi, Y., Abdul Rahman, R., \& Omar, N. (2013) Corporate governance mechanisms and voluntary disclosure in Saudi Arabia. Research Journal of Finance and Accounting. Vol.4. No.4. p 2222-2847.

Aljifri, K., Alzarouni, A., Ng, C. \& Tahir, M. (2014) The association between firm characteristics and corporate financial disclosures: evidence from UAE companies. International Journal of Business and Finance Research. Vol. 8, No 2.

Alhazaimeh, A., \& Palaniappan, R., \& Almsafir, M., (2013) The Impact of Corporate Governance and Ownership Structure on Voluntary Disclosure in Annual Reports among Listed Jordanian Companies. International Conference on Innovation, Management and Technology Research, Malaysia, 22 - 23 September, 2013

Arellano, M. \& Bover, O. (1995) Another look at the instrumental-variable estimation of error components models. Journal of Econometric, 68, 29-52.

Alsaeed, K. (2006). The association between firm-specific characteristics and disclosure: The case of Saudi Arabia. Managerial Auditing Journal, 21(5): 476-496. http://dx.doi.org/10.1108/02686900610667256

Al-Shammari, B., \& Al-Sultan, W. (2010). Corporate governance and voluntary disclosure in Kuwait. International Journal of Disclosure and Governance, 7(3), 262-280.

Arcay, M. R., \& Vázquez, M. (2005) Corporate characteristics, governance rules and the extent of voluntary disclosure in Spain. Advances in Accounting, 21, 299-331.

Barako, D.G.; Hancock, P.; Izan, I.H.Y. (2006). Relationship between corporate governance attributes and voluntary disclosures in annual reports: The Kenyan experience. Financial Reporting, Regulation and 
Governance, 5(1): 1-26.

Barney, J. B. (2001). Is the resource-based "view" a useful perspective for strategic management research? Yes. Academy of management review, 26(1), 41-56.

Baydoun, N. \& Willett, R. (1997) Islam and accounting: ethical issues in the presentation of financial information, Accounting. Commerce \& Finance. The Islamic Perspective Journal. Vol. 1 No. 1. pp. 1-25.

Belkaoui, A., \& Kahl, A. (1978) Corporate Financial Disclosure in Canada. Research Monograph No. 1 of Canadian Certificate General Accountants Associations, June.

Blair, M. M., \& Roe, M. J. (Eds.). (1999). Employees and corporate governance. Brookings Institution Press.

Blundell, R. \& Bond, S. (1998) Initial conditions and moment restrictions in dynamic panel data models. Journal of Econometrics, 87, 115-143.

Binh, T.Q. (2012) Voluntary Disclosure Information in the Annual Reports of Non -Financial Listed Companies: The Case of Vietnam, Journal of Applied Economics and Business Research, 2(2) 69-90.

Bokpin, G.A.; Isshaq, Z. (2009). Corporate governance, disclosure and foreign share ownership on the Ghana Stock Exchange. Managerial Auditing Journal, 24(7): http://dx.doi.org/10.1108/02686900910975387

Botosan, C.A. (1997). Disclosure level and the cost of equity capital. The Accounting Review, 72(3): 323-349.

Brown, C, Nakata, Y., Reich, M, \& Ulman, L. (1997). International and comparative industrial relations: Work and pay in the United States and Japan. Oxford: Oxford University Press.

Camfferman, K. \& Cooke, T. (2002) An analysis of disclosure in the annual reports of UK and Dutch companies. Journal of International Accounting Research. Vol. 1(1) . 3-30.

Cerf, A.R. (1961). Corporate Reporting and Investment Decisions (1st ed.). United States, California, Berkeley, CA: University of California Press.

Chau, G.; Gray, S.J. (2010). Family ownership, board independence and voluntary disclosure: Evidence from Hong Kong. Journal of International Accounting, Auditing and Taxation, 19(2): 93-109. http://dx.doi.org/10.1016/j.intaccaudtax.2010.07.002

Cheng, E.C.M.; Courtenay, S.M. (2006). Board composition, regulatory regime and voluntary disclosure. The International Journal of Accounting, 41(3): 262-289. http://dx.doi.org/10.1016/j.intacc.2006.07.001

Cheung, Y-L.; Jiang, P.; Tan, W. (2010). A transparency disclosure index measuring disclosures: Chinese listed companies. Journal of Accounting and Public Policy, 29(3): 259-280. http://dx.doi.org/10.1016/j.jaccpubpol.2010.02.001

Chow, C., \& Wong-Boren, A. (1987) Voluntary financial disclosure by Mexican corporations. Accounting Review. Vol. 62(3). 533-541.

Cong, Y., \& Freedman, M. (2011) Corporate governance and environmental performance and disclosures. Advances in Accounting, 27(2), 223-232.

Cooke, T.E. (1989). Voluntary corporate disclosure by Swedish companies. Journal of International Financial Management and Accounting, 1(2): 171-195. http://dx.doi.org/10.1111/j.1467-646X.1989.tb00009.x

Cooke, T. (1996). The Influence of the keiretsu on Japanese corporate disclosure. Journal of International Financial Management and Accounting, 7(3), 191-214.

Cooper, P. \& Zainudin, F. (2009) Determinants Of International Variation In The Quality Of Corporate Responsibility Reporting. Working Paper, 2009 British Accounting Association Conference, Dundee, Scotland.

Cormier, D., Ledoux, M. \& Magnan, M. (2011) The Informational Contribution of Social and Environmental Disclosures for Investors. Management Decision. Vol. 49(8): 1276-1304.

Dye, R. A. \& Sridhar, S. S. (1995) Industry-Wide Disclosure Dynamics. Journal of Accounting Research. Vol. 33(1). p. $157-174$.

Eng, L.L.; Mak, Y.T. (2003). Corporate governance and voluntary disclosure. Journal of Accounting and Public Policy, 22(4): 325-345.

Elsayed, M. O., \& Hoque, Z. (2010). Perceived international environmental factors and corporate voluntary disclosure practices: an empirical study. The British Accounting Review, 42(1), 17-35. doi:10.1016/j.bar.2010.01.001

Gul, F.A.; Leung, S. (2004). Board leadership, outside directors' expertise and voluntary corporate disclosures. Journal of Accounting and Public Policy, 23(5): 351-379. http://dx.doi.org/10.1016/j.jaccpubpol.2004.07.001

Haat, M.H.C.; Rahman, A.R.; Mahenthiran, S. (2008). Corporate governance, transparency and performance of Malaysian companies. Managerial Auditing Journal, 23(8): 744-778. http://dx.doi.org/10.1108/02686900810899518

Haniffa, R. (2002) Social reporting disclosure-an Islamic perspective, Indonesian Management and Accounting Research, Vol. 1 No. 2, pp. 128-146.

Haniffa, R.M.; Cooke, T.E. (2002). Culture, corporate governance and disclosure in Malaysian corporations. 
Abacus, 38(3): 317-349. http://dx.doi.org/10.1111/1467-6281.00112

Huafang, X. \& Jianguo, Y., (2007) Ownership structure, board composition and corporate voluntary disclosure: Evidence from listed companies in China. Managerial Auditing Journal, Vol. 22 Iss: 6, pp.604 - 619. http://dx.doi.org/10.1108/02686900710759406

Haniffa, R. \& Hudaib, M.A. (2002) A theoretical framework for the development of the Islamic perspective of accounting, Accounting, Commerce \& Finance. The Islamic Perspective Journal. Vol. 6 Nos 1/2. pp. 1-71.

Hassan, O.A.G.; Giorgioni, G.; Romilly, P.; Power, D. (2009). The value-relevance of disclosure: Evidence from the emerging capital market of Egypt. The International Journal of Accounting, 44(1): 79-102. http://dx.doi.org/10.1016/j.intacc.2008.12.005

Ho, S.S.M.; Wong, K.S. (2001). A study of the relationship between corporate governance structures and the extent of voluntary disclosure. Journal of International Accounting, Auditing and Taxation, 10(2): 139-156. http://dx.doi.org/10.1016/S1061-9518(01)00041-6

Hossain, M. (2008) The extent of disclosure in annual reports of banking companies: The case of India. European Journal of Scientific Research. Vol. 23(4). 659-680.

Hossain, M.; Hammami, H. (2009). Voluntary disclosure in the annual reports of an emerging country: The case of Qatar. Advances in Accounting, Incorporating Advances in International Accounting, 25(2): 255-265.

Hossain, M.; Reaz, M. (2007). The determinants and characteristics of voluntary disclosure by Indian banking companies. Corporate Social Responsibility and Environmental Management, 14(5): 274-288. http://dx.doi.org/10.1002/csr.154

Hossain, M.; Perera, M.H.B.; Abdul Rahman, R. (1995). Voluntary disclosure in the annual reports of New Zealand companies. Journal of International Financial Management and Accounting, 6(1): 69-87. http://dx.doi.org/10.1111/j.1467-646X.1995.tb00050.x

Iatridis, G. (2008) Accounting disclosure and firms' financial attributes: Evidence from the UK stock market. International Review of Financial Analysis. Vol. 17(2). 219-241.

Inchausti, B.G. (1997). The influence of company characteristics and accounting regulation on information disclosed by Spanish firms. The European Accounting Review, 6(1): 45-68. http://dx.doi.org/10.1080/096381897336863

Jensen, M.C.; Meckling, W.H. (1976). Theory of the firm: Managerial behavior, agency costs and ownership structure. Journal of Financial Economics, 3(4): 303-360. http://dx.doi.org/10.1016/0304-405X(76)90025-8

Jiang, H., \& Habib, A. (2009) The impact of different types of ownership concentration on annual report voluntary disclosures in New Zealand. Accounting Research Journal, 22(3). 275-304.

Jiang, H., Habib, A., \& Hu, B. (2011) Ownership concentration, voluntary disclosures and information asymmetry in New Zealand. The British Accounting Review, 43(1), 39-53.

$\mathrm{Ku}$ Ismail, K. \& Chandler, R. (2005) Disclosure in the quarterly reports of Malaysian companies. Financial Reporting, Regulation \& Governance. Vol. 4(1), 1-25.

Kurawa, J., \& Kabara, A., (2014) Impact of Corporate Governance on Voluntary Disclosure by Firms in the Downstream Sector of the Nigerian Petroleum Industry. World Business Research Conference 21 - 23 April 2014, Novotel World Trade Centre, Dubai, UAE, ISBN: 978-1-922069-48-1

Leventis, S. \& Weetman, P. (2004) Voluntary disclosure in an emerging capital market: Some evidence from the Athens Stock Exchange. Advances in International Accounting. Vol. 17. 227-250.

Liu, X. \& Anbumozhi, V. (2009) Determinant Factors Of Corporate Environmental Information Disclosure: An Empirical Study of Chinese Listed Companies. Journal of Cleaner Production. Vol. 17(6): 593-600.

Lopes, A.B.; Alencar, R.C. (2010). Disclosure and cost of equity capital in emerging markets: The Brazilian case. The International Journal of Accounting, 45(4): 443-464. http://dx.doi.org/10.1016/j.intacc.2010.09.003

Lopes, P. T. \& Rodrigues, L. L. (2007) Accounting for financial instruments: An analysis of the determinants of disclosure in the Portuguese stock exchange. The International Journal of Accounting. Vol. 42(1), 25-56.

Maali, B., Casson, P. and Napier, C. (2006) Social reporting by Islamic banks, ABACUS, Vol. 42 No. 2, pp. 266-289.

Malone, D.; Fries, C.; Jones, T. (1993). An empirical investigation of the extent of Corporate financial disclosure in the oil and gas industry. Journal of Accounting, Auditing and Finance, 8(3): 249-273.

Mangena, M \& Tauringana, V. (2007) Corporate compliance with non-mandatory statements of best practice: the case of the ASB statement on interim reports. European Accounting Review. Vol. 16. No. 2, 399-427.

Marston, C. (2003). Financial reporting on the internet by leading Japanese companies. Corporate Communications: An International Journal, 8(1): 23-34. http://dx.doi.org/10.1108/13563280310458894

Marston, C.; Polei, A. (2004). Corporate reporting on the internet by German companies. International Journal of Accounting Information Systems, 5(3): 285-311. http://dx.doi.org/10.1016/j.accinf.2004.02.009

Meek, G.K.; Gray, S.J.; Roberts, C.B. (1995). Factors influencing voluntary annual report disclosures by US, UK and continental European multinational corporations. Journal of International Business Studies, 26(3): 555-572. http://dx.doi.org/10.1057/palgrave.jibs.8490186 
Michelon, G. \& Parbonetti, A. (2010) The Effects of Corporate Governance on Sustainability Disclosure. Journal of Management and Governance. DOI: 10.1007/s10997-010-9160-3.

Naser, K.; Al-hussaini, A.; Al-kwari, D.; Nuseibeh, R. (2006). Determinants of corporate social disclosure in developing countries: The case of Qatar. Advances in International Accounting, 19: 1-23. http://dx.doi.org/10.1016/S0897-3660(06)19001-7

Naser, K., Al-Khatib, K., \& Karbhari, Y. (2002) Empirical evidence on the depth of corporate information disclosure in developing countries: The case of Jordan. International Journal of Commerce and Management. Vol. 12(3), 122-155.

Ntim,C., Lindop, S., \& Thomas, D. (2013) Corporate governance and risk reporting in South Africa: A study of corporate risk disclosures in the pre- and post-2007/2008 global financial crisis periods. International Review of Financial Analysis. Vol. 30. 363-383.

Omar, B., \& Simon, J. (2011) Corporate aggregate disclosure practices in Jordan. Advances in Accounting. 27(1). $166-186$.

Ousama, A., \& Fatima, A. (2010) Voluntary disclosure by Shariah approved companies: an exploratory study. Journal of Financial Reporting and Accounting. Vol. 8 No. 1. pp. 35-49.

Owusu-Ansah, S. (1998). The impact of corporate attributes on the extent of mandatory disclosure and reporting by listed companies in Zimbabwe. The International Journal of Accounting, 33(5): 605-631. http://dx.doi.org/10.1016/S0020-7063(98)90015-2

Oyelere, P.; Laswad, F.; Fisher, R. (2003). Determinants of internet financial reporting by New Zealand companies. Journal of International Financial Management and Accounting, 14(1): 26-63. http://dx.doi.org/10.1111/1467-646X.00089

Patton, J.; Zelenka, I. (1997). An empirical analysis of the determinants of the extent of disclosure in annual reports of joint stock companies in the Czech Republic. The European Accounting Review, 6(4): 605-626. http://dx.doi.org/10.1080/09638189700000003

Peters, G.F. \& Romi, A.M. (2011) Greenhouse Gas Emission Accounting: The Effect Of Corporate Governance On Voluntary Disclosure. Working Paper, University of Arkansas and Indiana University, USA.

Prencipe, A. (2004) Proprietary costs and determinants of voluntary segment disclosure: evidence from Italian listed companies. European Accounting Review. Vol. 13(2), 319-340.

Riahi-Belkaoui, A. (2003). Intellectual capital and firm performance of US multinational firms: a study of the resource-based and stakeholder views. Journal of Intellectual capital, 4(2), 215-226.

Sallehuddin, M.R. \& Fadzil, F.H. (2013) Factors Influencing corporate Environmental Responsibility Disclosures: a case of Shariah compliant companies Listed in the Main Market of bursa Malaysia. Malaysian Management Review. Vol. 48 No. 1. ISSN 0025-1348.

Saravanakumar, S., Mahadevan, A, Sairam Subramaniam, B. \& Aarthy, A. (2012) An Empirical Investigation on the Announcement of Corporate Quarterly Results. International Journal of Multidisciplinary Research. Vol.2 Issue. ISSN 22315780.

Schadewitz, H., \& Blevins, D. (1998) Major determinants of interim disclosures in an emerging market. American Business Review. Vol. 16(1). 41-55.

Sejjaaka, S. (2007) Corporate mandatory disclosure by financial institutions in Uganda. Accounting, Banking and Corporate Financial Management in Emerging Economies Research in Accounting in Emerging Economies. Vol. 7, 119-143.

Singhvi, S.S.; Desai, H.B. (1971). An empirical analysis of the quality of corporate financial disclosure. The Accounting Review, 46(1): 120-138.

Stanny, E. \& Ely, K. (2008) Corporate Environmental Disclosure About The Effects Of Climate Change. Corporate Social Responsibility and Environmental Management. Vol. 15(6): 338-348.

Uyar, A. (2011). Firm characteristics and voluntary disclosure of graphs in annual reports of Turkish listed companies. African Journal of Business Management, 5(17): 7651-7657.

Uyar, A., \& Kilic, M., \& Bayyurt, N, (2013) Association between firm characteristics and corporate voluntary disclosure: Evidence from Turkish listed companies. Intangible Capital, 9(4), 1080-1112 http://dx.doi.org/10.3926/ic.439

Wang, K., Sewon, O., \& Claiborne, M. (2008) Determinants and consequences of voluntary disclosure in an emerging market: Evidence from China. Journal of International Accounting, Auditing and Taxation. Vol. 17(1).14-30.

Wallace, R. \& Naser, K. (1995) Firm-specific determinants of the comprehensiveness of mandatory disclosure in the corporate annual reports of firms listed on the stock exchange of Hong Kong. Journal of Accounting and Public Policy. 14(4). 311-368.

Wallace, R. \& Naser, K. (1995) Firm-specific determinants of the comprehensiveness of mandatory disclosure in the corporate annual reports of firms listed on the stock exchange of Hong Kong. Journal of Accounting and Public Policy. 14(4). 311-368. 
Wallace, R.S.O.; Naser, K.; Mora, A. (1994). The relationship between the comprehensiveness of corporate annual reports and firm characteristics in Spain. Accounting and Business Research, 25(97): 41-53.

Watson, A.; Shrives, P.; Marston, C. (2002). Voluntary disclosure of accounting ratios in the UK. British Accounting Review, 34(4): 289-313. http://dx.doi.org/10.1006/bare.2002.0213

Xiao, J. Z., Yang, H., \& Chow, C. W. (2004) The determinants and characteristics of voluntary Internet-based disclosures by listed Chinese companies. Journal of Accounting and Public Policy. Vol. 23(3).191-225. 